\title{
APPLICATION OF THE ELECTRO-FENTON PROCESS TO MESOTRIONE AQUEOUS SOLUTIONS: KINETICS, DEGRADATION PATHWAYS, MINERALIZATION, AND EVOLUTION OF TOXICITY
}

\author{
Minir Murati ${ }^{1}$, Nihal Oturan ${ }^{1}$, Zoran Zdravkovski ${ }^{2}$, Jasmina Petreska Stanoeva ${ }^{2}$, \\ Snezhana Efremova Aaron ${ }^{3}$, Jean-Jacques Aaron 1,", Mehmet A. Oturan ${ }^{1, *}$ \\ ${ }^{1}$ Université Paris-Est, Laboratoire Géomatériaux et Environnement (LGE), EA 4508, \\ 5 Boulevard Descartes, 77454 Marne-La-Vallée, France \\ ${ }^{2}$ Institute of Chemistry, Faculty of Natural Sciences and Mathematics, Ss. Cyril \& Metodius University, \\ Arhimedova 5, 1000 Skopje, Republic of Macedonia \\ ${ }^{3}$ Department of Medical Biochemistry, Medical Faculty, Ss. Cyril \& Metodius University, \\ 50 Divizija 6, 1000 Skopje, Republic of Macedonia \\ jeanjacquesaaron@yahoo.fr; mehmet.oturan@univ-paris-est.fr
}

The kinetics and the mechanism of degradation of the mesotrione herbicide by three electrochemical advanced oxidation processes (EAOPs) systems, namely electro-Fenton (EF) with $\mathrm{Pt}$ anode (EF-Pt), anodic oxidation with BDD anode (AO), and EF-boron-doped diamond anode (EF-BDD), were investigated in acidic aqueous solutions. The degradation of mesotrione obeyed apparent first-order reaction kinetics, and its absolute rate constant value with hydroxyl radicals at $\mathrm{pH} 3.0$, determined by the competitive kinetics method, was found to be $8.20 \times 10^{8} 1 \mathrm{~mol}^{-1} \mathrm{~s}^{-1}$. Fourteen different mesotrione degradation products were separated and/or identified using $\mathrm{HPLC} \mathrm{MS}^{n}$ analyses. A rationalized scheme is proposed for the reaction pathways of mesotrione degradation in the EF process. The mesotrione mineralization yield values ranged between about $58 \%$ and $97 \%$ for a $6 \mathrm{~h}$ electrolysis time, according to the type of EAOP system and the electrolysis current intensity value. The evolution of the toxicity of mesotrione aqueous solutions with electrolysis time $(t)$ was investigated during treatment by the EF-Pt and EF-BDD systems. Toxicity was measured with the Microtox ${ }^{\circledR}$ method, based on the luminescence inhibition of marine bacteria Vibrio fischeri. The curves of \% inhibition $v s$. time were found to depend on the toxicity of the formed mesotrione degradation products.

Keywords: mesotrione; electro-Fenton; BDD; hydroxyl radicals; degradation mechanism; mineralization; toxicity

\section{ПРИМЕНА НА ФЕНТОНОВ ЕЛЕКТРОПРОЦЕС НА ВОДЕН РАСТВОР ОД МЕЗОТРИОН: КИНЕТИКА, ПАТ НА ДЕГРАДАЦИЈА, МИНЕРАЛИЗАЦИЈА И ПРОМЕНА НА ТОКСИЧНОСТА}

Кинетиката и механизмот на деградација на хербицидот мезотрион беше испитана во закиселен воден раствор со примена на три напредни електрохемиски процеси на оксидација: електро-Фентон (electro-Fenton - EF) со Pt анода (EF-Pt), анодна оксидација со BDD анода (AO) и $\mathrm{EF}$ збогатен со бор на дијамантска анода (EF-BDD). Деградацијата на мезотрионот очигледно се базира на кинетички реакции од прв ред и беше најдено дека апсолутната вредност на нејзината константа со хидроксидните радикали при $\mathrm{pH} 3,0$, определена со компетитивниот кинетички метод, изнесува $8,20 \times 10^{8} 1 \mathrm{~mol}^{-1} \mathrm{~s}^{-1}$. Четиринаесетте продукти на деградација на мезотрионот беа сепарирани и/или идентификувани со примена на $\operatorname{HPLC} \mathrm{MS}^{n}$. За реакциониот пат на деградацијата на мезотрионот со примена на EF-процеси е предложена рационализирана шема. Минерализацијата на мезотрионот води до вредност во опсег помеѓу 58\% и $97 \%$ за 6 h време на електролиза, во согласност со типот на системот ЕАОР и вредноста на јачината на струјата при електролизата. Беше проучена промената на токсичноста на водниот раствор од мезотрионот во зависнот од 
времето на електролиза $(t)$ во текот на третманот со системите EF-Pt и EF-BDD. Токсичноста беше мерена со примена на метод Microtox ${ }^{\circledR}$, базиран на луминисцентната инхибиција на морската бактерија Vibrio fischeri. Беше најдено дека кривите за процентот на инхибиција во однос на времето зависат од токсичноста на формираните деградациони продулти на мезотрионот.

Клучни зборови: мезотрион; електро-Фентон; BDD; хидроксилни радикали; механизам на деградација; минерализација; токсичност

\section{INTRODUCTION}

In developed countries, pesticides are extensively utilized for agricultural purposes, and, because of that, they represent the most frequent organic micropollutants found in environmental waters, including surface water, groundwater, and wastewater effluents $[1,2]$. A subject of great concern is that most pesticides and/or their metabolites, especially organochlorine ones, may persist for long periods in the environment, disperse globally, and bioaccumulate in food chains with possible impacts on human health and on other living organisms, even at low concentration levels. Also, they may volatilize from water bodies into the atmosphere, and, because of their resistance to degradation reactions in air, travel long distances before being re-deposited far from the points of release [3, 4]. For these reasons, a number of pesticides and other persistent organic micropollutants present in aquatic systems raise considerable toxicological concerns and they have become a serious environmental problem [5].

Therefore, many appropriate, efficient, and rapid water-treatment technologies have been developed and implemented to remove these micropollutants from natural waters [5]. Among recent technologies, advanced oxidation processes (AOPs), based on the in situ production of strong oxygenbased oxidizers, such as very reactive and nonselective hydroxyl radicals $(\cdot \mathrm{OH})$, by different reactions, including conventional Fenton reaction, ozonation, heterogeneous photocatalysis, photoFenton process, and the electro-Fenton (EF) process, are generally considered as the most effective and ecologically friendly emerging approaches for treating persistent organic pollutants present at low concentrations in natural waters [6-12].

As a substitute to atrazine, which is a herbicide widely used for the protection of corn crops and banned in European countries in 2003, a new triketone (TRK) class of selective herbicides, including essentially mesotrione and sulcotrione, has been developed and marketed in the 2000s, in order to control a wide range of grasses and broadleaf weeds in corn crops [13, 14]. In the framework of the development of efficient water-treatment methods, the degradation of sulcotrione and/or mesotrione has been described in recent years by several AOPs, such as photolysis, EF, Fenton's reagent, and ozonation [13-17]. In particular, we have recently investigated, using the EF process in acidic aqueous solutions, the degradation reactions of both TRK herbicides, which obeyed apparent first-order kinetics, and we have performed a preliminary identification study of the formed main cyclic or aromatic TRK by-products, and we have also examined the mineralization of aqueous solutions of sulcotrione and mesotrione in terms of total organic carbon [16]. However, the detailed identification of the TRK by-products has not been carried out, and the degradation pathway of sulcotrione and mesotrione during the EF process is still unknown. Moreover, a very important point for the practical application of AOPs for water treatment is the evolution of the toxicity of both TRK herbicides. Until now, only one study concerning the potential toxicity of sulcotrione and mesotrione and their degradation products toward two microorganisms, including Tetrahymena pyriformis and Vibrio fischeri (Microtox test), has been reported by Bonnet et al. [18], who found that most of the degradation products showed a greater toxicity than the parent molecules.

In the present work, we chose to investigate the reactivity of mesotrione, the newest member of the triketone class of herbicides, during the electrochemical advanced oxidation processes (EAOPs) using three different systems, namely anodic oxidation with BDD anode (AO), classical $\mathrm{EF}$ with $\mathrm{Pt}$ anode (EF-Pt), and EF with a borondoped diamond anode (EF-BDD), under several experimental conditions. Our main goals were to identify the various mesotrione degradation products, to propose a rationalized scheme for the mesotrione degradation pathways during the electro-Fenton process, to study the extent and evolution of the mesotrione mineralization process, and to assess the evolution of the general toxicity of mesotrione solution and its oxidation intermediates during treatment by the above-mentioned EAOPs. 


\section{EXPERIMENTAL}

\subsection{Reagents and chemicals}

Mesotrione (2-[2-nitro-4 (methylsulfonyl) benzoyl]-1,3-cyclohexanedione), Pestanal ${ }^{\circledR}$ grade, was purchased from Riedel-de-Haën, and used as received. Cyclohexane 1,3-dione (CHD) and (2-chloro-4-methylsulfonyl) benzoic acid (CMBA) were obtained from Acros Organics France. 4-(methylsulfonyl)-2-nitro-benzoic acid (MNBA) was purchased from Fluorochem. Inorganic reagents such as $\mathrm{Na}_{2} \mathrm{SO}_{4}$, ammonium iron(II) sulfate hexahydrate [Mohr salt, $\mathrm{Fe}\left(\mathrm{NH}_{4}\right)_{2}\left(\mathrm{SO}_{4}\right)_{2}$ - $\left.6 \mathrm{H}_{2} \mathrm{O}\right]$ as $\mathrm{Fe}^{2+}$ source (catalyst), $\mathrm{H}_{3} \mathrm{PO}_{4}, \mathrm{Na}_{2} \mathrm{CO}_{3}$, and $\mathrm{NaHCO}_{3}$ were supplied by Aldrich. All mesotrione aqueous solutions were prepared with pure water obtained from a Millipore Simplicity 185 system.

\subsection{Electrochemical cell}

For the EAOPs applied in this study, the electrolyses were performed as described previously [19] in a small, open, cylindrical, one-compartment electrochemical cell of $6-\mathrm{cm}$ diameter and $250 \mathrm{ml}$ capacity in which the herbicide aqueous solutions were placed. Either a cylindrical Pt mesh or a $25 \mathrm{~cm}^{2}$ BDD electrode (BDD thin-film deposited on a niobium substrate from CONDIAS GmbH, Germany) was used as the anode, and a large surface carbon-felt $(14 \mathrm{~cm} \times 5 \mathrm{~cm}$ each side, $0.5 \mathrm{~cm}$ width - Carbone Lorraine) as the cathode. In all cases, the anode was centered in the electrochemical cell and was surrounded by the cathode, which covered the inner wall of the cell. $\mathrm{H}_{2} \mathrm{O}_{2}$ was produced from reduction of $\mathrm{O}_{2}$ dissolved in the solution. Continuous saturation of this gas at atmospheric pressure was ensured by bubbling compressed air that had been passed through a frit at about $11 \mathrm{~min}^{-1}$, starting $10 \mathrm{~min}$ before the electrolysis to reach a stationary $\mathrm{O}_{2}$ concentration.

The mesotrione aqueous solutions submitted to electrolysis contained $0.1 \mathrm{mM} \mathrm{Fe}{ }^{2+}$ as catalyst and $0.05 \mathrm{M} \mathrm{Na}_{2} \mathrm{SO}_{4}$ as supporting electrolyte, and were investigated at $\mathrm{pH} 3.0$ and at room temperature $\left(23 \pm 2{ }^{\circ} \mathrm{C}\right)$, by applying a constant electrolysis current intensity $(I)$ in the range $50-1000 \mathrm{~mA}$. Indeed, $\mathrm{pH} 3.0$ is considered as the optimum $\mathrm{pH}$ value for the Fenton's reaction, and the use of a $\mathrm{Fe}^{2+}$ concentration of $0.1 \mathrm{mM}$ is recommended as the catalyst optimum amount to realize the electroFenton process with a minimized contribution of parasitic reactions [9]. All trials were performed with $220 \mathrm{ml}$ solutions, vigorously stirred by a magnetic PTFE bar during the treatment to enhance the mass transport towards the electrodes.

\subsection{Electrolysis and mineralization procedures}

The electrolyses were performed with a Hameg HM8040 triple power supply at constant current. This instrument also displayed the cell voltage during the treatments. The solution $\mathrm{pH}$ was measured with a CyberScan pH $1500 \mathrm{pH}$-meter from Eutech Instruments. The mineralization of the mesotrione solutions was assessed from the decay of their dissolved organic carbon, assumed to be the total organic carbon (TOC) when treating a highly water-soluble organic compound, such as this herbicide. The corresponding analytical parameters were determined on a Shimadzu VCSH TOC analyzer. Samples withdrawn from the treated solutions at different electrolysis times were micro-filtered onto a hydrophilic membrane (Millex-GV Millipore, pore size $0.22 \mu \mathrm{m}$ ) before analysis. Reproducible TOC values with $\pm 2 \%$ accuracy were found using the non-purgeable organic carbon method.

\subsection{Kinetic procedures}

The mesotrione degradation kinetics were followed by reversed-phase HPLC using a Merck Lachrom liquid chromatograph equipped with a L-7100 pump, fitted with a Purospher RP-18, 5 $\mu \mathrm{m}, 25 \mathrm{~cm} \times 4.6 \mathrm{~mm}$ (i.d.) column at $40^{\circ} \mathrm{C}$, and coupled with a L-7455 photodiode array detector selected at the optimum wavelength of $256 \mathrm{~nm}$. The HPLC system was controlled with an EZChrom Elite 3.1 software. The study of the mesotrione decay, as well as the experiments involving the determination of the absolute rate constant with 4-hydroxybenzoic acid (4-HBA), were carried out isocratically with a $1 \% \mathrm{H}_{3} \mathrm{PO}_{4}$ methanol/water 40:60 ( $V / V)$ mixture as mobile phase. A flow rate of $0.8 \mathrm{ml} \mathrm{min}{ }^{-1}$ and an injection volume of $20 \mu \mathrm{l}$ were utilized. The corresponding mesotrione retention time $\left(t_{\mathrm{R}}\right)$ was $12.5 \mathrm{~min}$. The standard solutions used to establish the calibration curves of mesotrione were prepared in a methanol/water medium.

\subsection{LC/DAD/ESI-MS ${ }^{n}$ analysis of the degradation products}

The mesotrione degradation products were identified by LC-MS/MS analysis. Liquid chromatographic separations were carried out on a 150 
$\mathrm{mm} \times 4.6 \mathrm{~mm}, 5 \mu \mathrm{m}$ XDB-C18 Eclipse column (Agilent, USA). The mobile phase consisted of two solvents: water-formic acid (1\%) (A) and methanol (B). A linear gradient starting with $10 \%$ B (0-5 $\min$ ) was used to reach $50 \% \mathrm{~B}$ at $20 \mathrm{~min}$ and $75 \%$ $\mathrm{B}$ at $30 \mathrm{~min}$ and back to $10 \% \mathrm{~B}$ at $35 \mathrm{~min}$. The

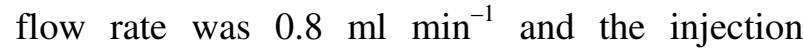
volume $30 \mu \mathrm{l}$. The $\mathrm{LC}$ system was equipped with an Agilent 1100 series diode array detector (DAD) and a mass detector in series (Agilent Technologies, Waldbronn, Germany), which consisted of a G1312A binary pump, a G1313A auto-sampler, a G1322A degasser, and a G1315B photo-diode array detector, controlled by ChemStation software (Agilent, v.08.03). Spectral data from all peaks were accumulated in the range: $\lambda=190-600 \mathrm{~nm}$, and the chromatograms were recorded at $\lambda=230$, 254, 270, and $300 \mathrm{~nm}$. The mass detector was a G2445A Ion-Trap Mass Spectrometer (MS) equipped with an electrospray ionization (ESI) system operated in the negative mode and controlled by LCMSD software (Agilent, v.6.1.). Nitrogen was used as nebulizing gas at a pressure of 50 psi and the flow rate was adjusted to 121 $\min ^{-1}$. The heated capillary and the voltage were maintained at $350{ }^{\circ} \mathrm{C}$ and $4 \mathrm{kV}$, respectively. The full scan mass covered the range from $\mathrm{m} / \mathrm{z}$ 15-500. Collision-induced fragmentation experiments were performed in the ion trap using helium as collision gas, with a voltage ramping cycle from 0.3 up to 2 $\mathrm{V}$. The maximum accumulation time of ion trap and the number of MS repetitions to obtain the MS average spectra were set at $300 \mathrm{~ms}$ and 5, respectively. The MS spectra were collected in the positive and negative ion modes, but since for most of the compounds the negative ion mode was more efficient, sensitive, and selective than the positive ion mode, we only present the MS spectra obtained in the negative ion mode.

\subsection{Chromatographic analysis of the short-chain carboxylic acids}

Generated short-chain carboxylic acids were identified and quantified by ion-exclusion HPLC using an Alltech liquid chromatograph equipped with a Model 426 pump, fitted with a Supelcogel H, $9 \mu \mathrm{m}, 25 \mathrm{~cm} \times 4.6 \mathrm{~mm}$ (i.d.), column (Supelco) at room temperature, and coupled with a Dionex AD20 UV detector selected at $\lambda=220 \mathrm{~nm}$. A $0.1 \%$ $\mathrm{H}_{3} \mathrm{PO}_{4}$ solution was used as the mobile phase at a flow rate of $0.5 \mathrm{ml} \mathrm{min}^{-1}$, and the injection volume was $50 \mu \mathrm{l}$. The measurements were controlled through Chromeleon SE software. The identification of short-chain carboxylic acids was carried out by comparing the $t_{\mathrm{R}}$ and UV spectra with those of pure standards.

\subsection{Toxicity measurements}

The toxicity of mesotrione and of its degradation products was measured on samples collected at different times of treatment by the EF process. We selected the Microtox ${ }^{\circledR}$ method, based on the determination of the bioluminescence of the bacteria Vibrio fischeri. These toxicity measurements were performed with a luminometer Berthold Autolumat Plus LB 953, according to the international procedure (OIN 11348-3). The bioluminescent bacteria and a bacteria activation reagent, LCK 487 LUMISTOX, were provided by Hach Lange France SAS. All bioluminescence measurements were realized on solutions containing an initial mesotrione concentration of $c_{0}$ $=0.1 \mathrm{mM}\left(33.9 \mathrm{mg} \mathrm{l}^{-1}\right)$, which were electrolyzed at a constant current intensity value $I=1000 \mathrm{~mA}$, and on a blank $\left(c_{0}=0 \mathrm{mM}\right)$. In all cases, the bioluminescence intensity of Vibrio fischeri bacteria was measured after 5 and $15 \mathrm{~min}$ of exposure to the samples of treated mesotrione solutions at $22 \pm 2{ }^{\circ} \mathrm{C}$. The procedure of the toxicity measurements, which included five steps, has been described in detail in a previous paper [20].

\section{RESULTS AND DISCUSSION}

\subsection{Kinetic study of the mesotrione degradation}

\subsubsection{Mesotrione degradation kinetic characteristics}

We performed the oxidative degradation kinetics experiments of the herbicide mesotrione, occurring during the electro-Fenton process, at room temperature in diluted acidic $(\mathrm{pH}=3.0)$ aqueous solutions (mesotrione initial concentration $=0.1 \mathrm{mM}$ ), containing catalytic amount of ferrous ions $\left(\left[\mathrm{Fe}^{2+}\right]=0.1 \mathrm{mM}\right)$ and $50 \mathrm{mM} \mathrm{Na} 2 \mathrm{SO}_{4}$. Decay of the initial herbicide concentration was monitored by HPLC. All kinetic curves of mesotrione degradation, obtained with several EAOP systems, including AO, EF-Pt, and EF$\mathrm{BDD}$, for $I=50,100,200,300$, and $500 \mathrm{~mA}$, were characterized by a regular and rather fast exponential herbicide concentration decrease with the electrolysis time (Figure 1). As we previously indicated, we observed analogous kinetic curves for the sulcotrione degradation during the electroFenton process, utilizing the same EAOP systems [16]. Similar to sulcotrione, mesotrione was quasicompletely removed within about 5-20 min, depending on the applied current intensity and the EAOP system. Moreover, we found that the meso- 
trione degradation rate significantly increased with the applied current intensity value, the herbicide removal time being moderately shorter with the EF-BDD system than with the EF-Pt system. These results suggest that the efficiency of the mesotrione removal increases in the presence of a more intense electrolysis current, and with a BDD electrode. We explain the observed degradation rate increase with the applied current intensity by the $\mathrm{H}_{2} \mathrm{O}_{2}$ production rate increase and the acceleration of the catalytic cycle $\mathrm{Fe}^{3+} / \mathrm{Fe}^{2+}$, on the one hand, and by the acceleration of the BDD $(\cdot \mathrm{OH})$ formed at the surface of the BDD anode on the other hand. This should yield an enhancement of the $\cdot \mathrm{OH}$ radicals formation rate and, therefore, an increase of the mesotrione oxidation rate.
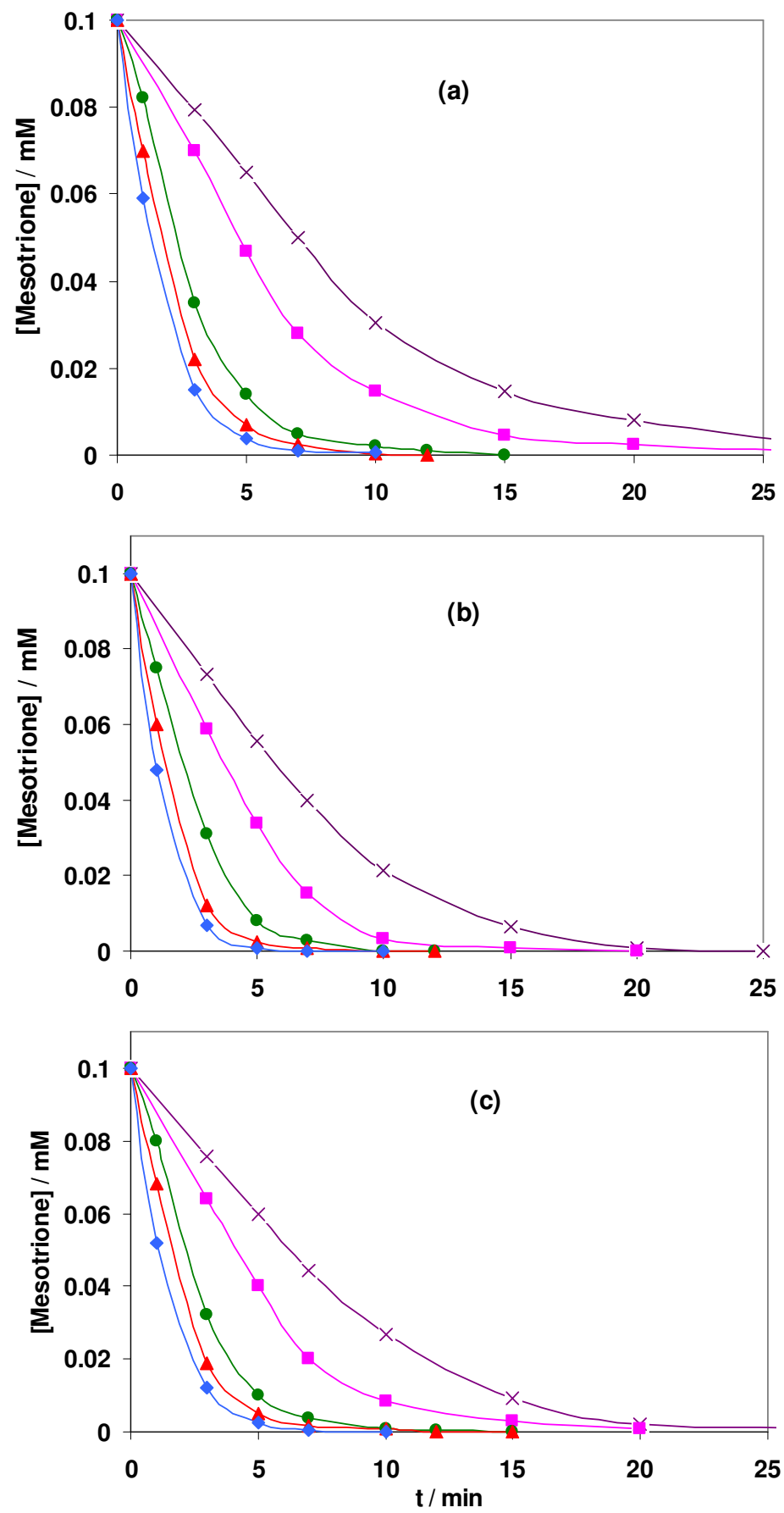

Fig. 1. Effect of the current intensity $(I)$ on the degradation kinetics of mesotrione $\left(c_{0}=0.1 \mathrm{mM}\right)$ in aqueous solution by the - $\mathrm{OH}$ radicals formed during the treatment by various electrochemical advanced oxidation processes (EAOPs):

(a) EF-Pt, (b) OA, and (c) EF-BDD. I (mA): 50 (-x-), $100(-\mathbf{m -}), 200(-\bullet-), 300(-\mathbf{\Lambda}-)$, and $500(-\bullet-)$.

$\left[\mathrm{Fe}^{2+}\right]=0.1 \mathrm{mM}, \mathrm{pH}=3.0,\left[\mathrm{Na}_{2} \mathrm{SO}_{4}\right]=50 \mathrm{mM}$ 


\subsubsection{Evaluation of the mesotrione hydroxylation absolute rate constant}

As previously described in detail [16], we evaluated the absolute rate constant of the hydroxylation reaction between mesotrione (Mesot) and - OH radicals $\left(k_{\mathrm{abs}(\text { Mesot })}\right)$ by the method of competition kinetics with a reference compound, namely 4-HBA (4-hydroxybenzoic acid), for which the corresponding hydroxylation absolute rate constant is well documented $\left(k_{\mathrm{abs}(4-\mathrm{HBA})}=1.63 \times 10^{9} \mathrm{M}^{-1} \mathrm{~s}^{-1}\right)$ [21].

Under the above-mentioned standard experimental conditions, the concentration of hydroxyl radicals could be considered as practically constant, and the quasi-stationary state kinetic hypothesis was applied to their concentration. Consequently, we assumed that the hydroxylation reaction of mesotrione and 4-HBA with $\cdot \mathrm{OH}$ obeyed a pseudo-first-order kinetic.

We measured the kinetics of the competitive decay of 4-HBA and mesotrione under standard experimental conditions and in the presence of equal concentrations of mesotrione and 4-HBA. For these kinetic measurements, we considered the first $20 \mathrm{~min}$ of the electro-Fenton treatment, assuming first-order kinetics and no side-reactions of mesotrione or of 4-HBA. Under these conditions, the apparent rate constants of mesotrione $\left[k_{\text {app(Mesot })}\right]$ and of 4-HBA $\left[k_{\mathrm{app}(4-\mathrm{HBA})}\right]$ were given by the slopes of the corresponding straight lines of $\ln \left(c_{0} / c_{\mathrm{t}}\right)=f(t)$ plot (Figure 2). $k_{\text {app(Mesot) }}$ and $k_{\text {app(4-HBA) }}$ were found to be $0.070 \mathrm{~min}^{-1}$ and $0.188 \mathrm{~min}^{-1}$, respectively.

Combination of the pseudo-first-order integrated kinetic equations allowed us to calculate the hydroxylation absolute rate constant of mesotrione as follows:

$$
\begin{aligned}
k_{\mathrm{abs}(\text { Mesot })}= & k_{\mathrm{abs}(4-\mathrm{HBA})} \times\left(k_{\mathrm{app}(\text { Mesot) }} / k_{\mathrm{app}(4-\mathrm{HBA})}\right)= \\
& 8.20 \times 10^{8} \mathrm{M}^{-1} \mathrm{~s}^{-1}
\end{aligned}
$$

Also, it is interesting to note that the absolute rate constant value of mesotrione is large, which again confirms the very high reactivity of hydroxyl radicals towards mesotrione herbicide, in good agreement with kinetic data previously reported for the oxidation of other organic pollutants $[16,22-25]$.

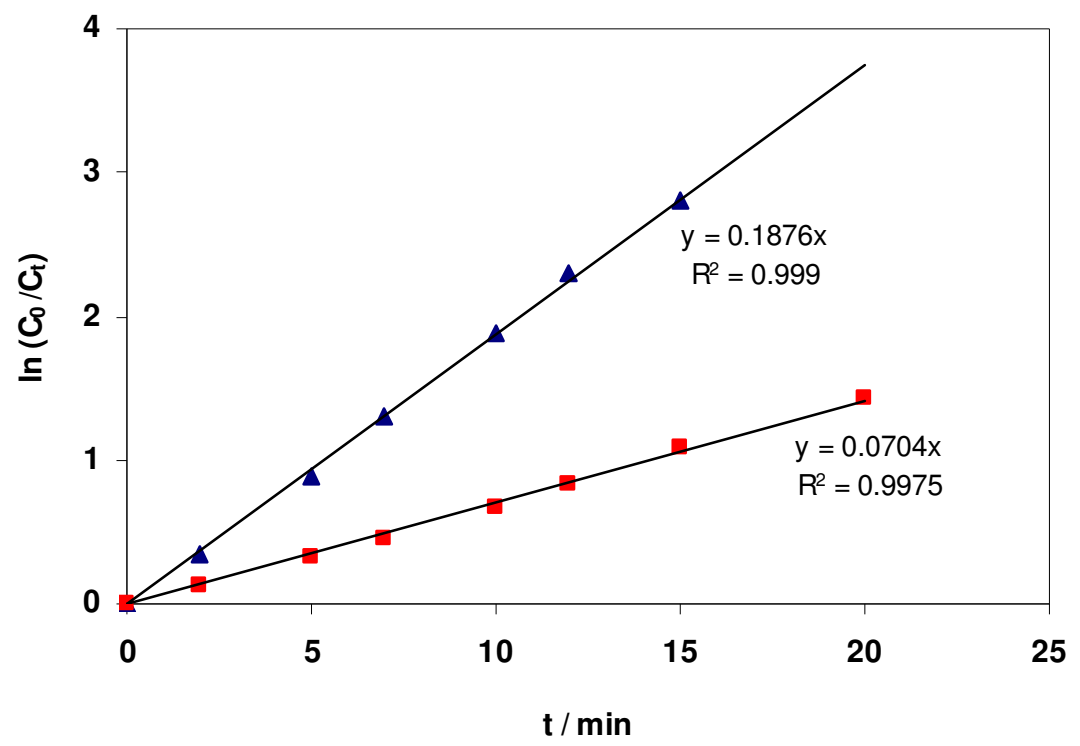

Fig. 2. Determination of the rate constant, $k_{\mathrm{abs}}(\mathrm{Mesot} / \cdot \mathrm{OH})$ from apparent rate constants $\left(k_{\mathrm{app}}\right)$ by using the competitive kinetic method. (- - -) Mesotrione, (- $\boldsymbol{\Delta}$-): 4-HBA. Operating conditions: [Mesotrione] $=[4-\mathrm{HBA}]=0.1 \mathrm{mM}, I=50 \mathrm{~mA}$, $\left[\mathrm{Fe}^{2+}\right]=0.1 \mathrm{mM}, \mathrm{pH}=3.0,\left[\mathrm{Na}_{2} \mathrm{SO}_{4}\right]=50 \mathrm{mM} . k_{\text {abs(Mesot })}=8.2 \times 10^{8} \mathrm{M}^{-1} \mathrm{~s}^{-1}$

\subsection{Identification of mesotrione degradation products and proposed reaction pathways}

In order to elucidate the mesotrione degradation mechanism, it was necessary to precisely identify the primary by-products formed during the initial part of the electro-Fenton process. The identification of these degradation products also consti- tutes the key to improving the electro-Fenton process overall efficiency, and to developing possible application for water treatment. Indeed, in general, hydroxyl radicals are reacting non-selectively, and, therefore, a number of by-products are formed at relatively low concentration levels. We identified the main mesotrione degradation products by $\mathrm{LC} / \mathrm{DAD} / \mathrm{ESI}^{-M \mathrm{MS}^{\mathrm{n}}}$ analysis. 
In the first part of this analysis, we determined the number of main mesotrione degradation products, and we investigated the evolution with the electrolysis time of mesotrione and its degradation products by HPLC-DAD. The HPLCDAD chromatograms (recorded at $\lambda=254 \mathrm{~nm}$ ) of several samples of treated mesotrione solutions, collected at electrolysis times of 10, 20, 30, and 45 min during the electro-Fenton process, indicated the presence of at least fifteen peaks corresponding to mesotrione and various formed by-products. As expected, we observed a marked evolution of the relative intensity of the HPLC-DAD peaks with the electrolysis time. For example, the peak of mesotrione strongly diminished from 10 to $20 \mathrm{~min}$ of electrolysis and practically disappeared after 45 min, whereas the peaks of the by-products evolved quite regularly with time. This behavior is in good accordance with our results previously obtained for the EF degradation of mesotrione and sulcotrione [16].
We also recorded the HPLC-DAD chromatograms, obtained at two different wavelengths $(\lambda=254$ and $300 \mathrm{~nm})$, after $30 \mathrm{~min}$ of electrolysis, and showed the presence of fifteen peaks attributed to mesotrione and to fourteen degradation products (I-XIV), tentatively identified by high performance liquid chromategraphy-mass spectrometry (HPLC-MS) analysis (Figure 3). As already stated, it is apparent from these chromatograms that, after $30 \mathrm{~min}$, the relative intensity of the peak corresponding to mesotrione (peak M) was much smaller than those measured for shorter electrolysis times, which indicated that mesotrione underwent a very important degradation during the $\mathrm{EF}$ process. Another important point is that the relative intensities of the HPLC-DAD peaks considerably varied according to the selected UV wavelength, which may be explained by the differences of maximum UV absorption wavelengths and molar absorption coefficients of the various by-products.

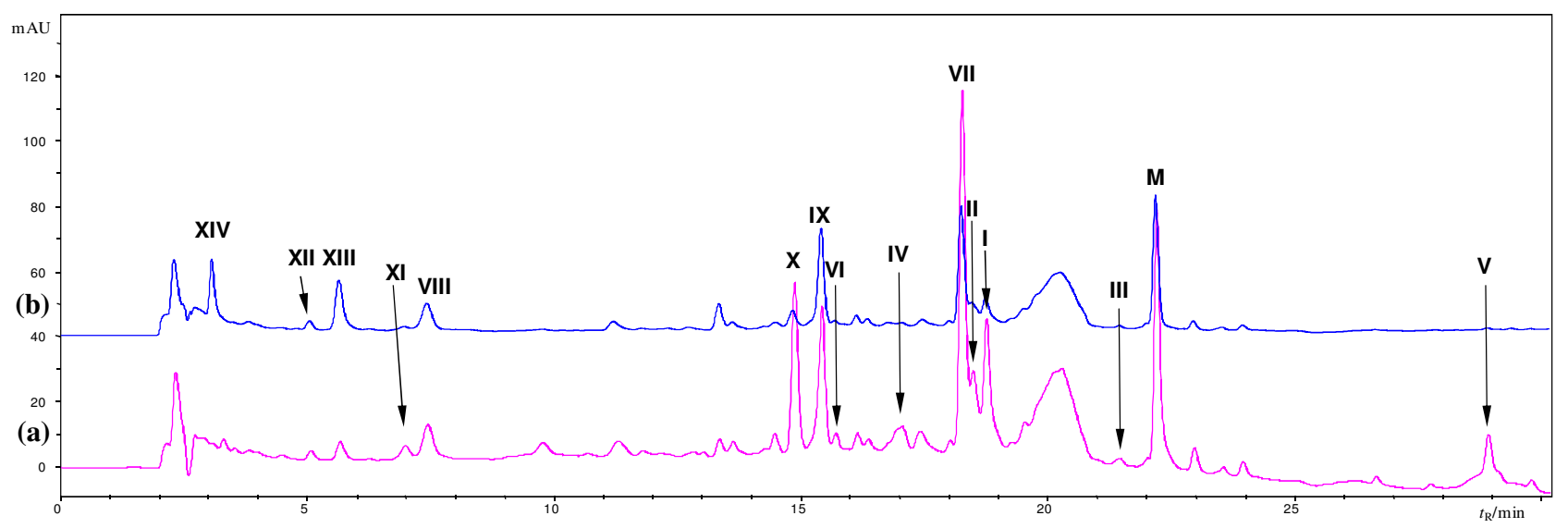

Fig. 3. HPLC-DAD chromatograms, obtained at two different absorption wavelengths, $254 \mathrm{~nm}$ (curve a) and $300 \mathrm{~nm}$ (curve b). Both chromatograms were performed on mesotrione solution samples collected at a 30 min electrolysis time. For peak numbers, see Table 1. Peak M corresponds to mesotrione

Secondly, in order to identify the mesotrione by-products, we analyzed the $\mathrm{MS}^{2}$ spectra for mesotrione and each of the fourteen EF degradation products (Figure 4). We also summarize in Table 1 the retention times $\left(t_{\mathrm{R}}\right)$ and the UV absorption maxima, as well as the MS and $\mathrm{MS}^{2}$ molecular/fragment masses and the HPLC-MS peak relative areas in the negative ionization mode, for mesotrione and for each of the fourteen $\mathrm{EF}$ degradation products. The molecular structure of mesotrione was confirmed with an authentic sample, while that of the by-products was only determined from their mass fragmentation spectra. Among these fourteen compounds, eleven were identified with certainty, whereas the four others, including compounds I, II, III, and V could not be identified unambiguously.

Careful inspection of the identified mesotrione degradation products confirmed the presence, at small concentrations, of two by-products, namely VIII (4-(methylsulfonyl)-2-nitrobenzoic acid, MNBA) and XIV (cyclohexane 1,3-dione, CHD), already identified in our previous paper [16], and of two other, more abundant compounds, including IX (1-nitro-3-methylsulfonylphenol) and XI (1-nitro-3methylsulfonylbenzene), all of them being attributed to classical oxidation by $\cdot \mathrm{OH}$ EF processes of mesotrione (oxidative dissociation products) (Table 1 and Figure 4). 

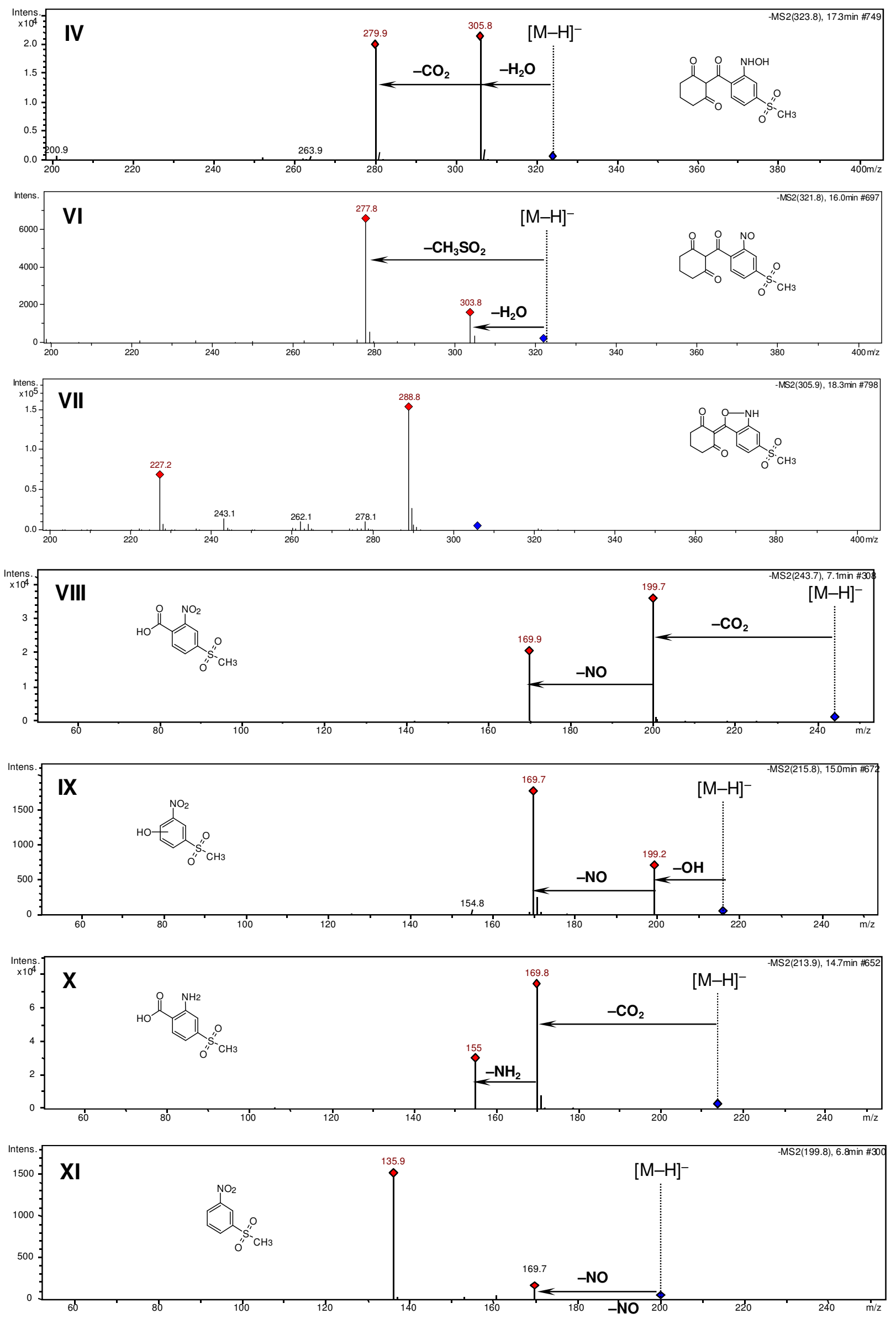

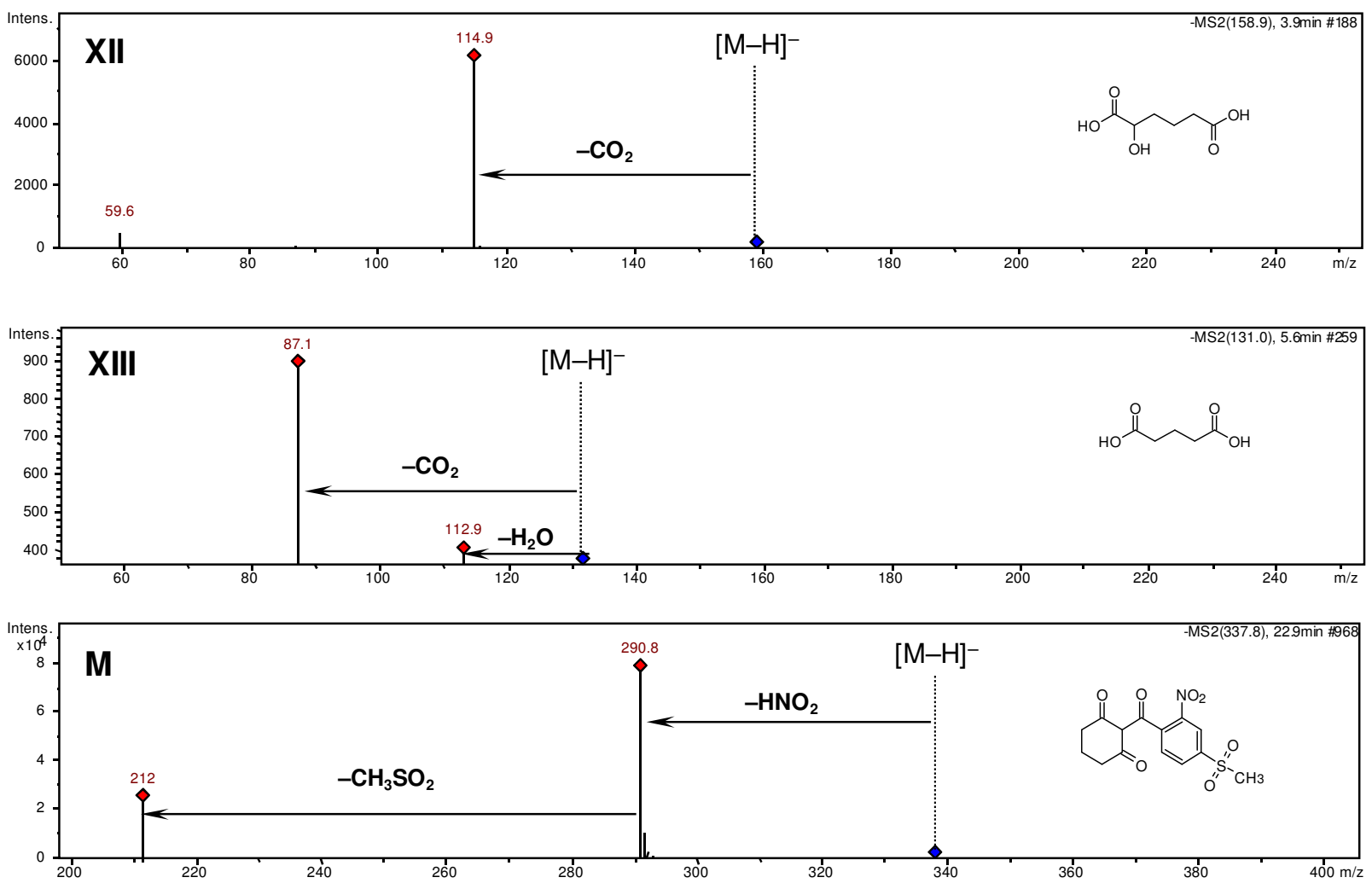

Fig. 4. $\mathrm{MS}^{2}$ spectra for mesotrione $(\mathrm{M})$ and the identified degradation products of the electro-Fenton process.

The proposed molecular structure of the numbered by-products is given for each spectrum.

The mesotrione molecular structure was also confirmed with an authentic sample

Besides that, surprisingly, several other relatively abundant by-products, such as a hydroxylamine derivative of mesotrione (2-[2hydroxylamino-4 (methylsulfonyl)benzoyl]-1,3cyclohexanedione, IV), a 2,1-benzisoxazole-like mesotrione derivative (VII), and 2-amino-4-methylsulfonylbenzoic acid (AMBA, X) (Table 1 and Figure 4), clearly resulted from an EF degradation process involving cathodic reduction of the mesotrione nitro substituent, in contrast with previous other EF studies, in which a dominant hydroxyl oxidation mechanism of aromatic substituents was generally accepted and no cathodic reduction process was found $[9,10,26]$. However, our present results appear to be in agreement with a recent paper reporting the mechanism and performance of 2,4,6trinitro-toluene (TNT) removal from contaminated water using the EF process [27]. In this work, the authors proposed a degradation scheme showing a complex alternation of oxidation and reduction processes of the nitro moieties, evidencing the importance of the electrochemical reduction in the whole EF process [27]. Moreover, it is interesting to mention that, similar to our results involving mesotrione EF reduction, several researchers reported the occurrence of several by-products (or metabolites) during mesotrione reactions of biodegradation and environmental transformation, due to the mesotrione hydroxylation and nitro group reduction, such as the mesotrione hydroxylamine derivative (IV), the 2,1-benzisoxazole-like mesotrione derivative (VII), and AMBA (X) [15, 28-31].

Finally, it is worthwhile to note that the dominant HPLC peaks in the samples of mesotrione solutions, collected at an electrolysis time of $45 \mathrm{~min}$ during the EF process, corresponded to 1-(methylsulfonyl)-3-nitrobenzene (XI), 2-amino-4-(methylsulfonyl) benzoic acid (X), and two dicarboxylic acids (2hydroxy-hexane-1,6-dioic acid, XII, and butane-1,4dioic acid, XIII). Moreover, we could not detect any hydroxyl-substituted aromatic by-products, possibly due to the substitution of nitro, nitroso, or methylsulfonyl groups by hydroxyl radicals.

Based on the major degradation products identified by LC-MS ${ }^{n}$, we were able to propose rationalized reaction pathways for the degradation of mesotrione under electro-Fenton conditions (Figure 5). 


\section{T a b le 1}

HPLC, UV spectra and MS data for mesotrione (M) and its fourteen degradation products (I-XIV), tentatively identified by MS ${ }^{2}$ in the EF reaction mixtures

\begin{tabular}{|c|c|c|c|c|c|c|c|c|c|c|}
\hline \multirow{2}{*}{ Compound $^{a}$} & \multirow{2}{*}{$t_{\mathrm{R}} / \mathrm{min}$} & \multirow{2}{*}{$\mathrm{UV} \max ^{b}$} & \multirow{2}{*}{$\mathrm{MW}^{c}$} & \multirow{2}{*}[\mathrm{M}-\mathrm{H}]{$^{-}$} & \multirow{2}{*}{$\mathrm{MS}^{2}$ fragments $^{d}$} & \multirow{2}{*}{ Formula } & \multicolumn{4}{|c|}{ Relative Area $(\%)^{e}$} \\
\hline & & & & & & & M-10 & M-20 & M-30 & M-45 \\
\hline I & 18.7 & 234,328 & 373 & 372 & 354,266 & & 1.8 & 2.5 & 4.8 & 7.3 \\
\hline II & 18.5 & 254,232 & 359 & 358 & $296,214,170$ & $\mathrm{C}_{14} \mathrm{H}_{16} \mathrm{NO}_{4} \mathrm{~S}$ & $\mathrm{ND}^{f}$ & 2.0 & 2.0 & 2.1 \\
\hline III & 22.7 & 256 & 355 & 354 & $336,307,228$ & $\mathrm{C}_{14} \mathrm{H}_{13} \mathrm{NO}_{8} \mathrm{~S}$ & 1.1 & 0.6 & 0.4 & $\mathrm{ND}$ \\
\hline M & 22.9 & 250,302 & 339 & 338 & 291,212 & $\mathrm{C}_{14} \mathrm{H}_{13} \mathrm{NO}_{7} \mathrm{~S}$ & 8.7 & 2.1 & 1.6 & 0.3 \\
\hline IV & 17.3 & $232,254,354$ & 325 & 324 & 306,280 & $\mathrm{C}_{14} \mathrm{H}_{15} \mathrm{NO}_{6} \mathrm{~S}$ & 0.3 & 0.9 & 2.8 & 4.4 \\
\hline V & 28.9 & 230,280 & 325 & 324 & $306,289,227$ & $\mathrm{C}_{14} \mathrm{H}_{15} \mathrm{NO}_{6} \mathrm{~S}$ & 2.6 & 2.5 & 2.3 & 0.4 \\
\hline VI & 16.0 & $236,262,330$ & 323 & 322 & 304,278 & $\mathrm{C}_{14} \mathrm{H}_{13} \mathrm{NO}_{6} \mathrm{~S}$ & 0.8 & 1.0 & 0.6 & 0.4 \\
\hline VII & 18.2 & 248,320 & 307 & 306 & $289,262,243,227$ & $\mathrm{C}_{14} \mathrm{H}_{13} \mathrm{NO}_{5} \mathrm{~S}$ & 30.3 & 22.2 & 17.7 & 4.0 \\
\hline VIII & 7.0 & 258,302 & 245 & 244 & 200,170 & $\mathrm{C}_{8} \mathrm{H}_{7} \mathrm{NO}_{6} \mathrm{~S}$ & 1.5 & 1.8 & 2.5 & 4.9 \\
\hline IX & 15.0 & 248,302 & 217 & 216 & 200,170 & $\mathrm{C}_{7} \mathrm{H}_{7} \mathrm{NO}_{5} \mathrm{~S}$ & 5.4 & 5.4 & 5.1 & 3.9 \\
\hline$X$ & 14.7 & $232,250,354$ & 215 & 214 & 170,155 & $\mathrm{C}_{8} \mathrm{H}_{9} \mathrm{NO}_{4} \mathrm{~S}$ & 27.0 & 26.1 & 21.9 & 20.1 \\
\hline XI & 6.8 & 236 & 201 & 200 & 170,136 & $\mathrm{C}_{7} \mathrm{H}_{7} \mathrm{NO}_{4} \mathrm{~S}$ & 4.2 & 6.5 & 6.7 & 19.1 \\
\hline XII & 3.9 & 236,306 & 160 & 159 & 115,59 & $\mathrm{C}_{6} \mathrm{H}_{8} \mathrm{O}_{5}$ & 12.4 & 21.0 & 23.1 & 22.0 \\
\hline XIII & 5.6 & 278,304 & 132 & 131 & 113,87 & $\mathrm{C}_{5} \mathrm{H}_{8} \mathrm{O}_{4}$ & 3.7 & 4.9 & 8.2 & 10.2 \\
\hline XIV & 3.1 & 302 & 113 & 112 & - & $\mathrm{C}_{6} \mathrm{H}_{8} \mathrm{O}_{2}$ & 0.2 & 0.2 & 0.3 & 0.7 \\
\hline
\end{tabular}

${ }^{a} \mathrm{M}=$ mesotrione, IV = mesotrione hydroxylamine derivative; VI = 2-[4-(methylsulfonyl)-2-nitrosobenzoyl $]$ cyclohexane-1,3-dione; VII = 2,1-benzisoxazole like mesotrione derivative, VIII = 4-(methylsulfonyl)-2-nitrobenzoic acid, IX = 1-nitro-3-methylsulfonylphenol, X = 4-(methylsulfonyl)-2-aminobenzoic acid, XI = 1-(methylsulfonyl)-3-nitrobenzene,

$\mathrm{XII}=$ 2-hydroxyhexanedioic acid, XIII = pentanedioic acid, XIV = cyclohexane-1,3-dione. Compounds I, II, III and V could not be identified with certainty by the available MS ${ }^{\mathrm{n}}$ method ${ }^{b}$ Maximum wavelengths of the UV absorption spectra for each compound; ${ }^{c} \mathrm{MW}=$ molecular weight obtained from MS; ${ }^{d}$ Numbers in bold indicate the most abundant ion;

${ }^{e}$ The relative areas of HPLC peaks were measured for mesotrione solution samples obtained after electrolysis times of 10 min (M-10), 20 min (M-20), 30 min (M-30), and 45 min (M-45); ${ }^{f} \mathrm{ND}=$ not detected 
As can be seen in the figure, the mesotrione degradation seemed to follow two main competitive reaction pathways, namely $\mathrm{A}$, constituting successive steps of mesotrione oxidation, fragmentation, and hydroxylation, and $\mathrm{B}$, essentially attributed to the cathodic reduction of the mesotrione nitro moiety. These reaction pathways A and B led, respectively, to the formation of the corresponding nitro- and amino-benzene-substituted derivatives. The two corresponding dicarboxylic acids were obtained by oxidative degradation of the cyclohexadione moiety of mesotrione, whereas the amino-aromatic substituted deriveative (AMBA, X), was formed by reductive transformation of the $\mathrm{NO}_{2}$ moiety through the formation of intermediates bearing $\mathrm{NO}$ and $\mathrm{NHOH}$ groups, and involving $6 \mathrm{e}^{-} / 6 \mathrm{H}^{+}[27]$.

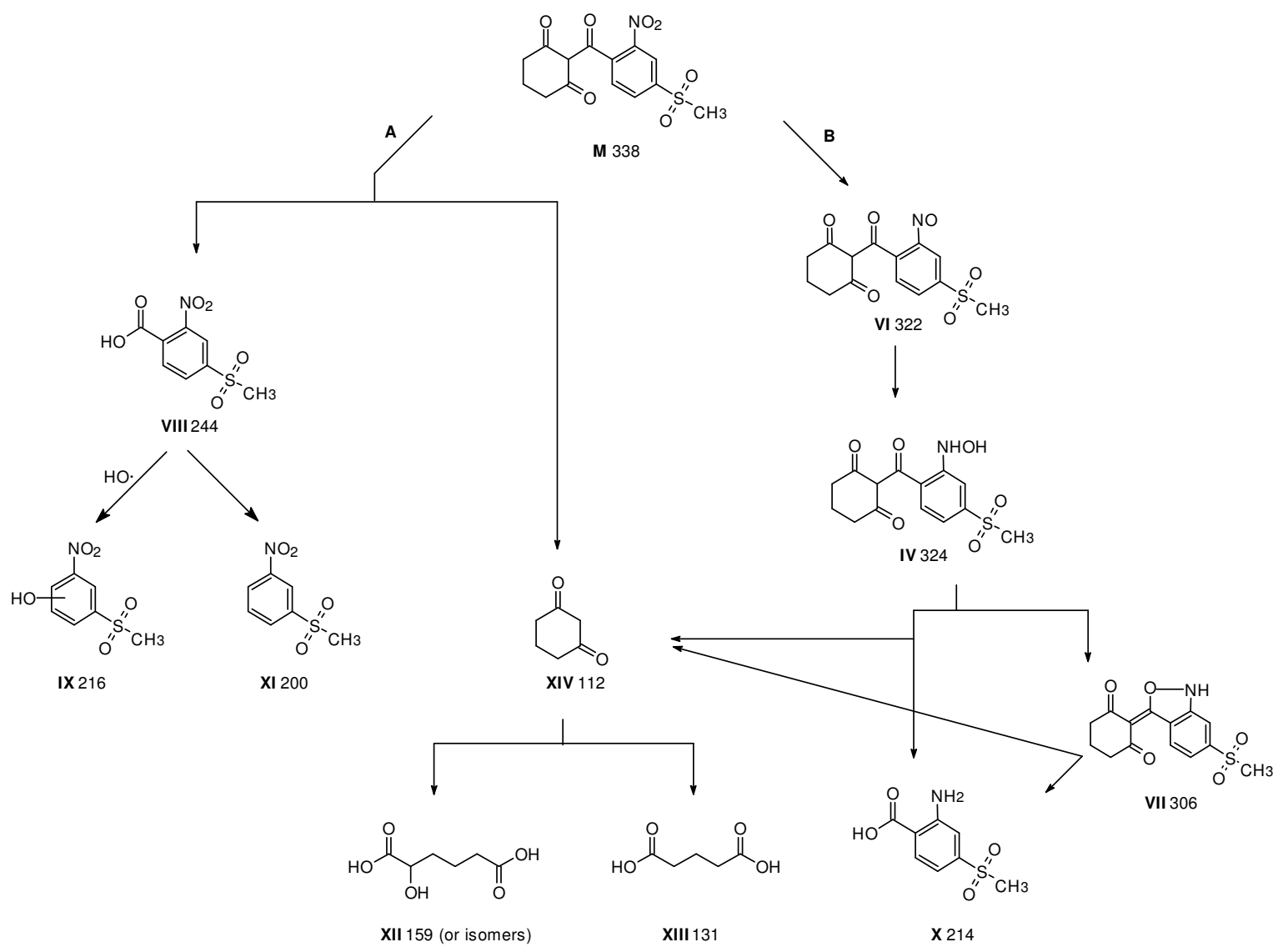

Fig. 5. Scheme of the reaction pathways, based on the identified major by-products, proposed for the degradation of mesotrione under the electro-Fenton (EF-BDD) conditions.

$\mathbf{M}=$ mesotrione, $\mathbf{I V}=$ mesotrione hydroxylamine derivative;

VI = 2-[4-(methylsulfonyl)-2-nitrosobenzoyl]cyclohexane-1,3-dione;

VII = 2,1-benzisoxazole-like mesotrione derivative,

VIII = 4-(methylsulfonyl)-2-nitrobenzoic acid, IX = 1-nitro-3-methylsulfonylphenol,

$\mathbf{X}=$ 4-(methylsulfonyl)-2-aminobenzoic acid, $\mathbf{X I}=1$-(methylsulfonyl)-3-nitrobenzene,

$\mathbf{X I I}=$ 2-hydroxyhexanedioic acid, $\mathbf{X I I I}=$ pentanedioic acid, $\mathbf{X I V}=$ cyclohexane-1,3-dione

\subsection{Study of the mineralization process}

To investigate the extent and evolution of the mineralization process, we performed electrolysis of mesotrione acidic aqueous solutions during $8 \mathrm{~h}$, and we measured the total organic carbon (TOC) evolution with electrolysis time. The curves of $[\mathrm{TOC}]=f$ (electrolysis time), obtained with the three different EAOP systems, namely EF-Pt, AO, and
EF-BDD, at various electrolysis current intensity values $(I=50-1000 \mathrm{~mA})$ and under the abovedescribed optimal conditions (mesotrione initial concentration $c_{0}=0.1 \mathrm{mM} ;\left[\mathrm{Fe}^{2+}\right]=0.1 \mathrm{mM} ; \mathrm{pH}=$ 3.0; $\left[\mathrm{NaSO}_{4}\right]=50 \mathrm{mM}$ ) are presented in Figure 6 . As can be seen, a progressive decrease of TOC takes place with electrolysis time for all the EAOP systems. The decay rates were significantly faster for the EF-BDD and AO systems than for the EF-Pt 
system, and increased with the current intensity value, as previously observed in the case of sulcotrione mineralization [16]. The mineralization yield values ranged between about $58 \%$ to $97 \%$ for a 6-h electrolysis time according to the type of EAOP system and the electrolysis current intensity value.

Under these conditions, the organic matter still present in the solution was essentially constituted of short-chain carboxylic acids. The mineralization rate, which was high at the beginning of the EAOP treatments, decreased progressively with the electrolysis time, reaching a plateau towards the end of the treatments. This rate decrease can be attributed to the transformation of the various identified cyclic or aromatic by-products into shortchain carboxylic acids by ring-opening reactions, as previously shown for the EF treatment of several other pesticides [9, 10, 32-34].
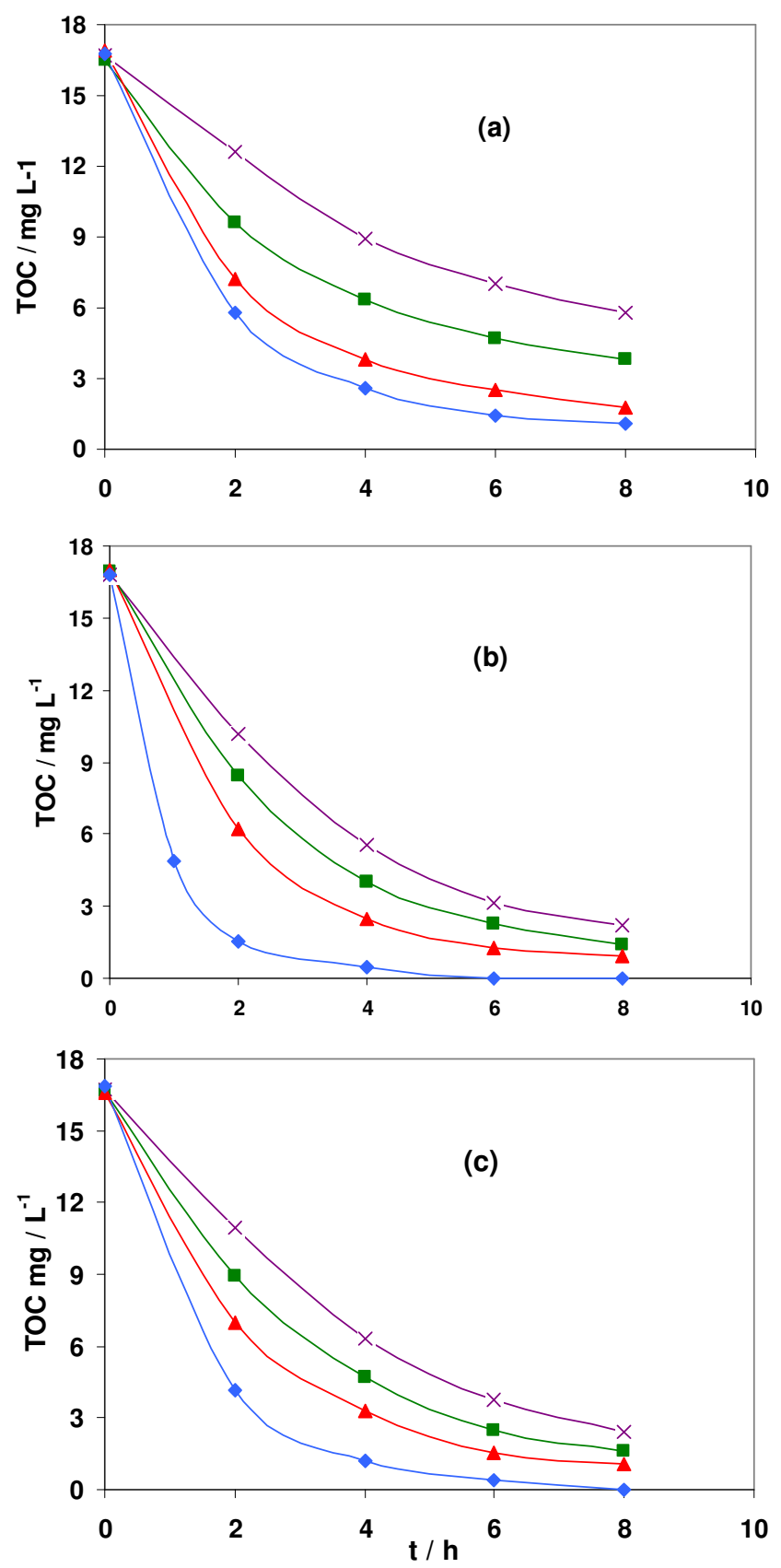

Fig. 6. Effect of the applied current on the mineralization kinetics of a mesotrione aqueous solution $\left(c_{0}=0.1 \mathrm{mM}\right) \mathrm{by}$ the $\cdot \mathrm{OH}$ radicals generated during the EAOPs treatment: (a) EF-Pt, (b) AO, and (c) EF-BDD. I (mA): 50 (-x-), 300 (- $\mathbf{-}-), 500$ (- $\left.\boldsymbol{\Lambda}_{-}^{-}\right)$, and $1000(--) .\left[\mathrm{Fe}^{2+}\right]=0.1 \mathrm{mM}, \mathrm{pH}=3.0,\left[\mathrm{NaSO}_{4}\right]=50 \mathrm{mM}$ 


\subsection{Evolution of the formed short-chain carboxylic acids}

We also investigated the evolution of the short-chain carboxylic acids generated during the mineralization of mesotrione by applying EF-Pt treatment.

Under our experimental conditions, we were able to identify by ion-exclusion UV-HPLC analysis the formation and disappearance of oxalic, pyruvic, acetic, and glycolic acids. Figure 7 shows the evolution of the concentration of the various short-chain carboxylic acids with time during the EF-Pt treatment of a $0.1 \mathrm{mM}$ mesotrione aqueous solution. Oxalic acid reached a maximum concentration of about $0.18 \mathrm{mM}$ for a 120 min electrolysis time, and was degraded by approximately $80 \%$ within about $480 \mathrm{~min}$, whereas pyruvic, acetic, and glycolic acids attained much smaller maximum concentrations of, respectively, about $0.018 \mathrm{mM}$ after approximately $12 \mathrm{~min}$ of electrolysis, 0.035 $\mathrm{mM}$ after a $123 \mathrm{~min}$ electrolysis time, and 0.022 $\mathrm{mM}$ after a $183 \mathrm{~min}$ electrolysis time. Then, these three carboxylic acids were slowly degraded, reaching a quasi-nil concentration within about 150 min of treatment for pyruvic acid, and $480 \mathrm{~min}$ of treatment for acetic and glycolic acids. As described in our previous study concerning the mineralization of sulcotrione, the formation and evolution of the same short-chain carboxylic acids with time followed an analogous behavior [16]. It is worthwhile to note that the formation of this type of carboxylic acids has been already demonstrated in the mineralization of acidic aqueous solutions of other aromatic herbicides, using the EF reaction $[9,10,25,33]$.

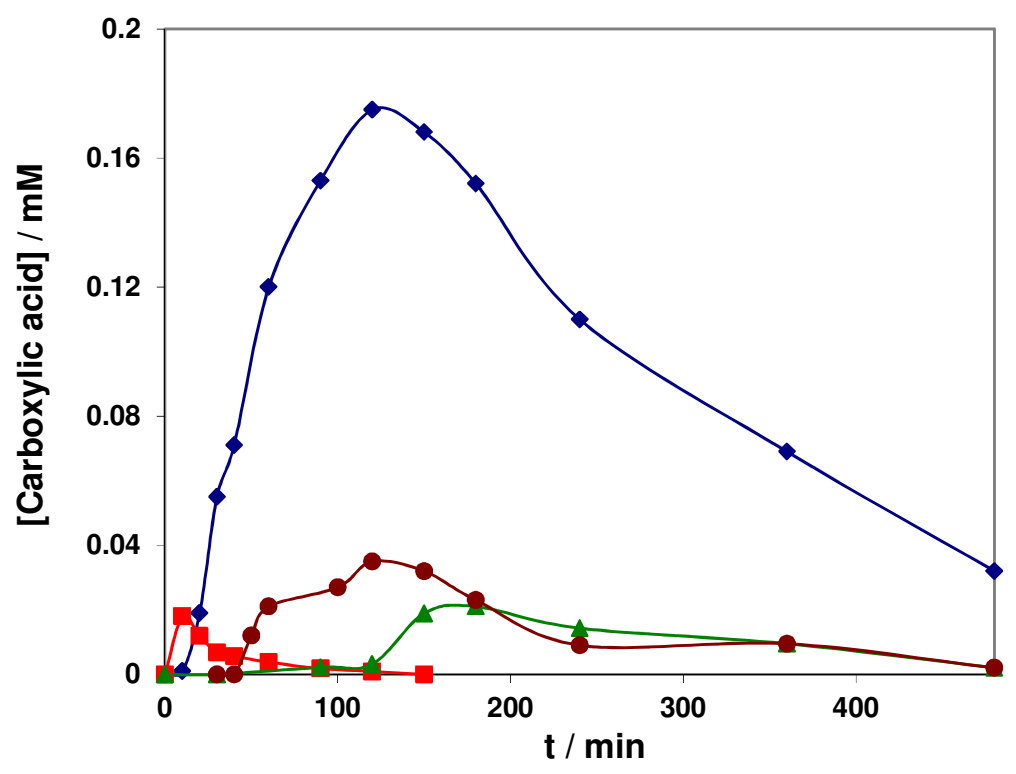

Fig. 7. Evolution of the concentration of generated short-chain carboxylic acids:

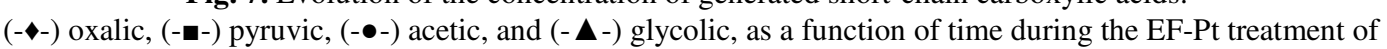
a $0.1 \mathrm{mM}$ mesotrione aqueous solution.

$I=300 \mathrm{~mA},\left[\mathrm{Fe}^{2+}\right]=0.1 \mathrm{mM}, \mathrm{pH}=3.0,\left[\mathrm{NaSO}_{4}\right]=50 \mathrm{mM}$

\subsection{Evolution of the toxicity of mesotrione and its by-products}

We studied the evolution of the toxicity of mesotrione toward Vibrio fischeri luminescent bacteria with the electrolysis time under EF treatment. We submitted $0.1 \mathrm{mM}$ mesotrione aqueous solutions to either the EF-Pt or the EFBDD system, by applying a constant current intensity value $I=1000 \mathrm{~mA}$. The curves of the percentage of bacteria luminescence inhibition versus electrolysis time (curves \% Inhibition vs. $t$ ) were obtained after exposure times of 5 and $15 \mathrm{~min}$ of luminescent bacteria to the mesotrione solutions, treated with either the EF-BDD (Figure 8, curves a) or the EF-Pt-systems (Figure 8, curves b). For both EAOP systems, the obtained curves were similar. In the case of the EF-BDD system, these curves displayed three successive parts. In the initial part, a strong increase of the bacteria luminescence inhibition occurred from about $23 \%$ to $100 \%$. Then, a plateau was reached for electrolysis times ranging between about $80-120$ and 80-180 $\mathrm{min}$, respectively, after $5 \mathrm{~min}$ and 15 
min of bacterial exposure, followed by a slower decrease until attaining a luminescence inhibition percentage value close to $0 \%$ for $t \sim 500 \mathrm{~min}$ (Figure 8 , curves a). In the case of the EF-Pt system, the curves \% Inhibition $v s$. $t$ presented an analogous shape, with an initial strong increase of the luminescence inhibition from about $20 \%$ to $95 \%$, followed by a plateau region for electrolysis times ranging between about 80 and $110 \mathrm{~min}$, after bacterial exposure times of 5 and $15 \mathrm{~min}$, and by a relatively slow decrease until practically reaching a nil luminescence inhibition percentage value for $t$ 600 min (Figure 8, curves b).

For all curves under EF-BDD or EF-Pt conditions, the observed important initial increase of luminescence inhibition, taking place during the first part of electrolysis (0-80 min), could be attributed to one (or several) formed by-product(s) being much more toxic than the parent molecule. The wide plateau region of luminescence inhibition, in the range $80-180 \mathrm{~min}$, according to the EAOP system and exposure time value, probably resulted from the complex concomitant partial accumulation and degradation of the various by-products in the reaction medium during the above-described reaction pathways (Figure 5). Indeed, very probably these mesotrione degradation products possessed more or less strong specific toxicities, because of their different molecular structures. Finally, the slow decrease of luminescence inhibition occurring between about 200 and 500 min of electrolysis could be explained by the progressive formation and disappearance of moderately toxic, short-chain carboxylic acids and the quasi-complete mesotrione mineralization.
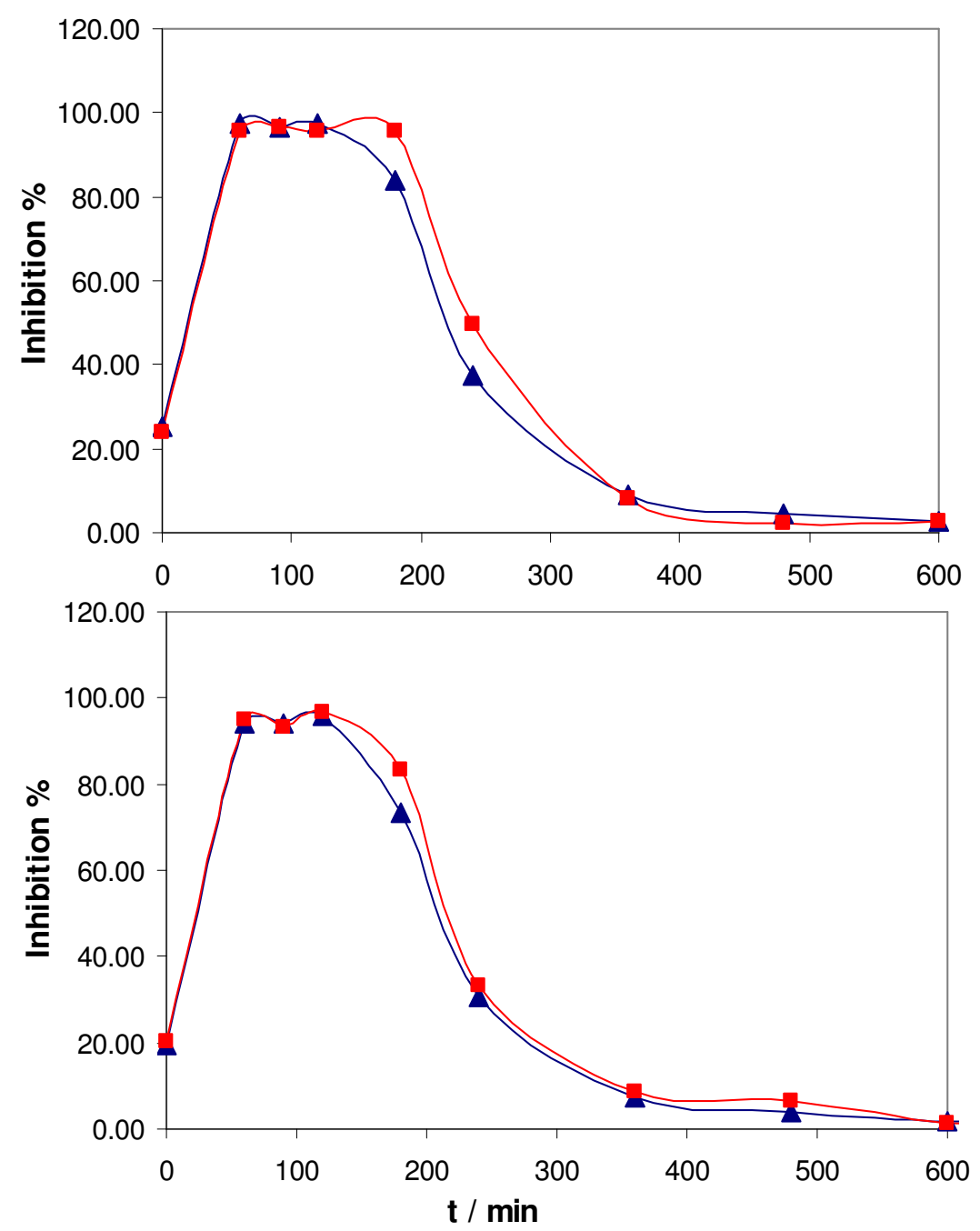

Fig. 8. Curves of Vibrio fischeri bacteria luminescence inhibition vs. electrolysis time, during the electro-Fenton treatment of mesotrione aqueous solutions after exposure times of $5 \min (\boldsymbol{\Delta})$ and $15 \min (\boldsymbol{\square})$. Curve (a): EF-BDD system; curve (b): EF-Pt system. [Mesotrione $]_{0}=0.1 \mathrm{mM}$. $\left[\mathrm{Fe}^{2+}\right]=0.1 \mathrm{mM}$. $\left[\mathrm{Na}_{2} \mathrm{SO}_{4}\right]=50 \mathrm{mM}, \mathrm{pH}=3.0, I=1000 \mathrm{~mA}$ 
Our interpretation of the global toxicity evolution of EF-treated mesotrione solutions, especially the initial strong increase in toxicity, which we attributed to the formation of one (or several) by-product(s) much more toxic than the parent molecule, was satisfactorily supported by the study of Bonnet et al. [18] on the toxicity of mesotrione, sulcotrione, and their degradation products toward $V$. fischeri bacteria. Indeed, these authors found that some of the mesotrione degradation products exhibited a greater toxicity than the parent molecule. For example, AMBA was much more toxic (Microtox $\mathrm{IC}_{50}=12.6 \pm 3.0$ $\mathrm{mg} \mathrm{l}^{-1}$ ) than mesotrione (Microtox $\mathrm{IC}_{50}=69.2 \pm$ $4.0 \mathrm{mg} \mathrm{l}^{-1}$ ), while MNBA was less toxic (Microtox $\mathrm{IC}_{50}=312.7 \pm 35.5 \mathrm{mg} \mathrm{l}^{-1}$ ) than the parent molecule [18]. We have also observed this behavior in the case of diuron, another herbicide, for which the oxidation intermediates were significantly more toxic than the parent compound [35]. It is worthwhile to note that, according to our own HPLC-MS ${ }^{\mathrm{n}}$ analysis, AMBA - the most toxic degradation product - was one of the most abundant by-products among those identified in the mesotrione reaction medium under EF conditions (Table 1). Therefore, our toxicity results appeared to be in good agreement with other literature studies of toxicity assessment [18, 20, 35].

\section{CONCLUSION}

In this work, we have investigated the degradation kinetics of the herbicide mesotrione in acidic aqueous solutions $(\mathrm{pH}=3)$ by using three EAOPs, including EF-Pt, EF-boron-doped diamond (EF-BDD), and anodic oxidation (AO) with a BDD anode. We have shown that the degradation rate significantly increased with the applied current intensity and that the herbicide removal time was notably shorter with the EFBDD system rather than with the EF-Pt system. By the competition kinetics method using equal initial concentrations of mesotrione and 4-hydroxybenzoic acid, we have determined a relatively high absolute rate constant value of $8.20 \times 10^{8} 1 \mathrm{~mol}^{-1} \mathrm{~s}^{-1}$ for the reaction of mesotrione with $\cdot \mathrm{OH}$ radicals. Another important point of our study is that we have been able to separate fourteen mesotrione degradation products formed during the EF treatment, and to identify with certainty by LC/DAD/ESI-MS ${ }^{n}$ analysis eleven of them, which were more or less abundant in the EF-treated mesotrione solutions. Also, this LC/DAD/ESI-MS ${ }^{\mathrm{n}}$ analysis of mesotrione by-products has allowed us to propose an original
EF-BDD degradation scheme of mesotrione, which exhibited a complex alternation of oxidation and reduction pathways, involving competitive steps of anodic oxidation, fragmentation, and aromatic hydroxylation, on the one hand, and of cathodic reduction of the mesotrione nitro moiety on the other. We have also demonstrated that the complete mineralization process of mesotrione, resulting from the EF treatment, took place during about 8 hours, and was characterized by the formation and disappearance of several short-chain carboxylic acids, including oxalic, pyruvic, acetic, and glycolic acids. Our study on the toxicity of mesotrione solutions submitted to the EF-Pt or the EF-BDD systems, based on the bioluminescence Microtox ${ }^{\circledR}$ method, revealed an evolution of the global toxicity characterized by three successive parts in the curves of luminescence inhibition $v s$. electrolysis time. In succession, there was a strong luminescence inhibition increase due to the formation of by-product(s) more toxic than mesotrione, a plateau due to a complex concomitant partial accumulation and degradation of variously toxic by-products, and a slow luminescence inhibition decrease resulting from the progressive formation and disappearance of moderately toxic, short-chain carboxylic acids. Overall, the quasi-complete disappearance of toxicity took place within several hours, which shows the necessity of submitting the mesotrione aqueous solutions to a relatively long EF treatment for efficient mesotrione mineralization and water decontamination.

Acknowledgements. Dr. Minir Murati gratefully thanks the French Embassy in Skopje (R. Macedonia) for a doctoral grant. Prof. Snezhana Efremova Aaron is grateful to the French Institute of Skopje (IFS) (R. Macedonia) for a financial contribution to her journey and research stay in France.

\section{REFERENCES}

[1] S. D. Richardson, A. D. Thruston, T. W. Collette, K. S. Patterson, J. Lykins, J.C. Ireland, Identification of $\mathrm{TiO}_{2} / \mathrm{UV}$ disinfection by-products in drinking water, Environ. Sci. Technol., 30, 3327-3334 (1996).

[2] T. Kowalkowski, M. Gadzala-Kopciuch, R. Kosobucki, K. Krupczynska, T. Ligor, B. Buszewski, Organic and inorganic pollution of the Vistula River basin, J. Environ. Sci. Health A, 42, 421-426 (2007).

[3] D. Tilman, J. Fargione, B. Wolff, C. D’Antonio, A. Dobson, R. Howarth, D. Schindler, W. H. Schlesinger, D. Simberloff, D. Swackhamer, Environmental change forecasting agriculturally driven global, Science, 292, 281-284 (2001). 
[4] K. C. Jones, P de Voogt, Persistent organic pollutants (POPs): state of the science, Environ. Pollution, 100, 209-221 (1999).

[5] R. P. Schwarzenbach, B. I. Escher, K. Fenner, T. B. Hofstetter, C. A. Johnson, U. von Gunten, B. Wehrli, The challenge of micropollutants in aquatic systems, Science, 313, 1072-1077 (2006).

[6] H. Zhang, D. B. Zhang, J. Y. Zhou, Removal of COD from landfill leachate by electro-Fenton method, $J$. Hazard. Mater., 135, 106-111 (2006).

[7] J. J. Pignatello, E. Oliveros, A. MacKay, Advanced oxidation processes for organic contaminant destruction based on the Fenton reaction and related chemistry, Critical Rev. Environ. Sci. Technol., 36, 184 (2006).

[8] M. Zhou, J. J. He, Degradation of azo dye by three clean advanced oxidation processes: wet oxidation, electrochemical oxidation and wet electrochemical oxidation - A comparative study, Electrochim. Acta, 53, 1902-1910 (2007).

[9] E. Brillas, I. Sirés, M. A. Oturan, Electro-Fenton process and related electrochemical technologies based on Fenton's reaction chemistry, Chem. Rev., 109, 6570-6631 (2009).

[10] M. A. Oturan, J. J. Aaron, Advanced Oxidation Processes in Water/Wastewater Treatment: Principles and Applications. A Review. Crit. Rev. Environ. Sci. Technol., in press (2013).

[11] M. A. Oturan, J. Pinson, J. Bizot, D. Deprez, B. Terlain, Reaction of inflammation inhibitors with chemically and electrochemically generated hydroxyl radicals. J. Electroanal.Chem., 334, 103-109 (1992).

[12] A. Kesraoui-Abdessalem, N. Oturan, N. Bellakhal, M. Dachraoui, M. A. Oturan, Experimental design methodology applied to electro-Fenton treatment for degradation of herbicide chlortoluron. Appl. Catal. B: Environ. 78, 334-341 (2008).

[13] H. Chaabane, E. Vulliet, F. Joux, F. Lantoine, P. Conan, J. F. Cooper, C. M Coste., Photodegradation of sulcotrione in various aquatic environments and toxicity of its photoproducts for some marine microorganisms, Water Res., 41, 1781-1789 (2007).

[14] A. Ter Halle, D. Drncova, C. Richard, Phototransformation of the herbicide sulcotrione on maize cuticular wax, Environ. Sci. Technol., 40, 2989-2995 (2006).

[15] A. Ter Halle, C. Richard, Simulated solar light irradiation of mesotrione in natural waters, Environ. Sci. Technol., 40, 3842-3847 (2006).

[16] M. Murati, N. Oturan, J. J. Aaron, A. Dirany, B. Tassin, Z. Zdravkovski, M. A. Oturan, Degradation and mineralization of sulcotrione and mesotrione in aqueous medium by the electro-Fenton process: A kinetic study, Environ. Sci. Pollut. Res., 19, 1563 1573 (2012).

[17] M. Jović, D. Manojlović, D. Stanković, B. Dojčinović, B. Obradović, U. Gašić, G. Roglić, Degradation of triketone herbicides, mesotrione and sulcotrione, using advanced oxidation processes, J. Hazard. Mater., 260, 1092-1099 (2013).

[18] J. L. Bonnet, F. Bonnemoy, M. Dusser, J. Bohatier, Toxicity assessment of the herbicides sulcotrione and mesotrione toward two reference environmental microorganisms: Tetrahymena pyriformis and Vibrio fischeri, Arch. Environ. Contamin. Toxicol., 55, 576583 (2008)

[19] A. Dirany, I. Sirés, N. Oturan, M. A. Oturan, Electrochemical abatement of the antibiotic sulfamethoxazole from water, Chemosphere, 81, 594-602 (2010).

[20] A. Dirany, S. Efremova Aaron, N. Oturan, I. Sirés, M. A. Oturan, J. J. Aaron, Study of the toxicity of sulfamethoxazole and its degradation products in water by a bioluminescence method during application of the electro-Fenton treatment, Anal. Bioanal. Chem., 400, 353-360 (2011).

[21] J. B. De Heredia, J. Torregrosa, J. R. Dominguez, J. A. Peres, Kinetic model for phenolic compound oxidation by Fenton's reagent, Chemosphere, 45, 85-90 (2001).

[22] R.W. Haag, D. Yao, Rate constants for reaction of hydroxyl radicals with several drinking water contaminants, Environ. Sci. Technol., 26, 1005-1013 (1992).

[23] F. Fdil, J. J. Aaron, N. Oturan, A. Chaouch, M. A. Oturan, Dégradation photochimique d'herbicides chlorophenoxyalcanoïques en milieu aqueux, Rev. Sci. Eau., 16, 123-142 (2003).

[24] M. A. Oturan, M. C. Edelahi, N. Oturan, J. J. Aaron, Kinetics of oxidative degradation/mineralization pathways of the phenylurea herbicides diuron, monuron and fenuron in water during application of the electro-Fenton process. Appl. Catal. B-Environ., 97, 82-89 (2010).

[25] N. Oturan, M. Panizza, M. A. Oturan. Cold incineration of chlorophenols in aqueous solution by electro-Fenton process. Effect of number and position of chlorine atoms on the degradation kinetics. J. Phys. Chem. A, 113, 10988-10993 (2009).

[26] M. Skoumal, C. Arias, P. Cabot, F. Centellas, A. Garrido, M. Rodriguez, E. Brillas, Mineralization of the biocide chloroxylenol by electrochemical advanced oxidation processes, Chemosphere, 71, 1718-1729 (2008).

[27] K. Ayoub, S. Nélieu, E. D. van Hullebusch, J. Labanowski, I. Schmitz-Afonso, A. Bermond, M. Cassir, Electro-Fenton removal of TNT: Evidences of the electro-chemical reduction contribution, Appl. Catal. B: Environ., 104, 169-176 (2011). 
[28] A. J. Gledhill, B. K. Jones, W. J. Laird, Metabolism of 2-(4-methylsulphonyl-2-nitrobenzoyl)-1,3-cyclohexanedione (mesotrione) in rat and mouse, Xenobiotica, 31, 733-747 (2001).

[29] P. Alferness, L. Wiebe, Determination of mesotrione residues and metabolites in crops, soil, and water by liquid chromatography with fluorescence detection, $J$. Agric. Food Chem., 50, 3926-3934 (2002).

[30] S. Durand, B. Légeret, A. S. Martin, M. Sancelme, A. M. Delort, P. Besse-Hoggan, B. Combourieu, Biotransformation of the triketone herbicide mesotrione by a Bacillus strain. Metabolite profiling using liquid chromatography/electrospray ionization quadrupole time-of-flight mass spectrometry, Rapid Commun. Mass Spectrom., 20, 2603-2613 (2006).

[31] I. Batisson, O. Crouzet, P. Besse-Hoggan, M. Sancelme, J. F. Mangot, C. Mallet, J. Bohatier, Isolation and characterization of mesotrione-degrading Bacillus sp. from soil, Environ. Pollution, 157, 11951201 (2009).
[32] M. A. Oturan, M. Pimentel, N. Oturan, I. Sirés, Reaction sequence for the mineralization of the shortchain carboxylic acids usually formed upon cleavage of aromatics during electrochemical Fenton treatment, Electrochim. Acta, 54, 173-182 (2008).

[33] I. Sirés, N. Oturan, M. A. Oturan, Electrochemical degradation of $\beta$-blockers. Studies on single and multicomponent aqueous solutions. Water Res., 44, 3109-3120 (2010).

[34] M. A. Oturan, N. Oturan, M. C. Edelahi, F. I. Podvorica, K. El Kacemi, Oxidative degradation of herbicide diuron in aqueous medium by Fenton's reaction based advanced oxidation processes. Chem. Eng. J., 171, 127-135 (2011).

[35] N. Oturan, S. Trajkovska, M. A. Oturan, M. Couderchet, J. J. Aaron, Study of the toxicity of diuron and its metabolites formed in aqueous medium during application of the electrochemical advanced oxidation process "electro-Fenton". Chemosphere, 73, 1550-1556 (2008). 
